\title{
VOWEL PHONEMES IN HINDI
}

\author{
Brahma Dutta Sharma \\ sharmaprofbd@yahoo.co.in \\ Kumaun University, India
}

Received December 11, 2018; Revised December 22, 2018; Accepted December 27, 2018

\begin{abstract}
An analysis of the present day Hindi, as spoken in the northern part of India, brings to light the fact that this language has at least twenty vowel phonemes, and not simply thirteen. Twelve of these twenty vowel phonemes are oral while eight of them are nasalized. Eighteen of them are pure vowels (monophthongs) while two of them are diphthongs. Two of the thirteen vowels included in the current list of alphabet have given place to two consonants with the result that they have ceased to exist. Most of these vowel phonemes occur in all the three positions, namely initial, medial and final, in the Hindi words.
\end{abstract}

Keywords: consonants, diphthongs, Hindi, meaning, monophthongs, vowel phonemes.

\section{Шарма Брахма Дутта. Голосні фонеми в гінді.}

Анотація. Аналіз поточного стану мови гінді, якою розмовляють у північній частині Індії, з'ясовує той факт, що в цій мові є принаймні двадцять голосних фонем, а не тринадцять. Дванадцять із цих двадцяти породжуються голосом, вісім - назалізовані. Вісімнадцять 3 них - чисті голосні (монофтонги), а дві представлено дифтонгами. Дві $з$ тринадцяти фонем, що включено до чинного алфавіту, поступилися місцем двом приголосним, а тому зникли з переліку. Більшість зі згаданих голосних зафіксовано в усіх трьох позиціях: на початку, всередині та в кінці слова.

Ключові слова: приголосні, дифтонги, гінді, значення, монофтонги, голосні фонеми.

\section{Introduction}

There is no unanimity among the linguists on the question as to how many vowel phonemes the Hindi language has. If one of them identifies only ten vowel phonemes in Hindi, there is another who identifies thirteen. And in most of the text books of Hindi grammar they give a list of twelve vowel phonemes. Therefore there exists the need of a thorough phonetic analysis of the language and a fresh effort to identify all the vowels of Hindi. It was in this context that I resolved to take up this task of finding out how many vowel phonemes the current Hindi has.

Since I am a native speaker of Hindi and have been using it during my seventysix year long stay in the Hindi heart-land I have every right to trust my intuition to arrive at conclusions about this language of mine. Since this language is being used by at least 500 million people in India alone, I thought, I would be serving a very large section of humanity by this research of mine. I consider myself qualified to do this job also because I have a forty year long experience of teaching linguistics in colleges and universities both at home in India and overseas.

\footnotetext{
(C) Sharma, Brahma Dutta, 2018. This is an Open Access article distributed under the terms and conditions of the Creative Commons Attribution 4.0 International Licence (http://creativecommons.org/licenses/by/4.0).

East European Journal of Psycholinguistics, 5(2), 71-91. https://doi.org/10.5281/zenodo.2583572
} 


\subsection{The Study}

\subsection{Survey of Literature}

John Shakespear identifies fourteen vowels in Hindustani alphabet but he mentions only ten of them while discussing pronunciation (Shakespear, 1845:6-12). There are two editions of Duncan Forbes' book of grammar one published in 1846 and another in 1856. Both of them largely deal with Urdu but a small discussion on the Devanagari script is also there in them. Duncan concerns himself with the Devanagari alphabet largely and there is no discussion about the sounds in either edition of the book. According to him: "The alphabet, as used for the Hindustani, consists of eleven vowel sounds, and thirty-three consonants" (Duncan, 1846:136) though in the plate that follows he has given fourteen vowels under the title Devanagri Alphabet. Tweedie identifies eight vowels (three short, five long vowels and no diphthongs) in Hindustani (Tweedie, 1900:3-4). Pahwa maintains that there are in all ten vowel sounds in the language [Hindustani]: three short vowels, five long vowels and two diphthongs (Pahwa, 1919:16-17).

Now let me turn my attention to the books that have Hindi in their title. In his Hindi Vyakaran [Grammar of Hindi] (1920) Kamta Prasad Guru identifies eleven vowels of which four (अ, इ, उ and ऋ) are short vowels, three (आ, ई, ऊ) long vowels and four (ए, ऐ, ओ, औ) diphthongs (Guru, 2009:46). Ram Lochan Sharan in his Hindi Vyakaran Chandrodaya considers twelve vowel sounds in Hindi which he further classifies as five short (अ, इ, उ, ए and ऋ) and seven long vowels (आ, ई, ऊ, ऋ, ऐ, ओ, औ, ऊ and ऋ). He also opines that four of these (ए, ऐ, ओ, औ) may also be called diphthongs (Sharan, 1920:5). Greaves writes: "The Hindi Alphabet differs but slightly from the Sanskrit. Indian grammarians are not unanimous in their views as to the number of the letters. For practical purposes, the number of the letters may be taken as 46, i.e., 11 vowels and 35 consonants. The 3 vowels ऋ, लृ, लॄ rí, lri and lrí, are pure Sanskrit and have no place in Hindi." (Greaves, 1921: 8) Suniti Kumar Chatterji uses the two terms viz. Hindi and Hindustani as synonyms and identifies three short (अ, इ, उ), five long (आ, ई, ऊ, ए, ओ) vowels and two diphthongs (ऐ, औ) in it (Chatterjee, 1942:139). Bhola Nath Tiwari has also identified 11 vowel sounds (अ, इ, उ, आ, ई, ऊ, ए, ओ, ऐ, औ, ऋ) in Hindi (Tiwari, 1958:5). While discussing Hindi alphabet Ram Chandra Verma in his Manak Hindi Vyakaran identifies 13 vowel letters of which four short vowels (अ, इ, उ and ऋ), long vowels (आ, ई, ऊ) and four diphthongs (ए, ऐ, ओ, औ) in Hindi; he does not take into account अं and अ: and discards them as they are not independent/pure vowels (Verma, 1994:8). Aryendra Sharma in his book identifies eleven vowels in Hindi. He also writes that any vowel "short or long can be nasalized." (Sharma, 1994:3-5) Rama Kant Agnihotri writes: "There are 10 short and long vowel sounds in Hindi." (Agnihotri, 2007:240) He asserts that the eleventh vowel ऋ exists in writing but has disappeared in speech (Agnihotri, 2007:243). Agnihotri further claims, "All vowel sounds also have their nasalised counterparts" (Agnihotri, 2007:243) and exemplifies them (Agnihotri, 2007:250-51). O N Kaul writes: "It 
[Hindi] has ten vowels...All vowels can be nasalized and nasalization is phonemic (Koul, 2008:4). Kaul mentions 10 oral and 10 nasal vowels in it. He writes, "Nasalization is phonemic in Hindi. All the vowels can be nasalized." (Koul, 2008:11) Uday Narayan Tiwari has identified six short (अ, ऑ, इ, उ, ऍ, ऑ) and seven long vowels (आ, ई, ऊ, ए, ओ, ऐ, औ) in Hindi. He further writes that all the vowel sounds of Hindi are used in the nasalised form also (Tiwari, 2009:242). Kapildev Dwivedi has identified 54 phonemes in Hindi of which the following 10 are the vowels: “अ आ इ ई उ ऊ ए ओ ऐ (अइ) औ (अउ)” (Dwivedi, 2016:148)

\section{Methods}

The data for analyzing the sounds was collected from the written as well spoken texts by the native speakers in a random manner. It was analysed by using comparison and contrast method.

\section{Results and Discussion}

Nasalisation of a phoneme in Hindi is a unique feature of the language. Nasal consonants that are independent phonemes are represented by separate graphemes but it is not the case with nasal vowels as is clear from the following figures:

Table 1

\begin{tabular}{|c|c|c|c|c|c|c|c|c|c|c|c|c|c|c|c|c|}
\hline \multirow{4}{*}{$\begin{array}{c}\text { Voicing } \rightarrow \\
\text { Aspiration } \rightarrow \\
\begin{array}{c}\text { kanthya } \\
\text { (Guttural) }\end{array}\end{array}$} & \multicolumn{8}{|c|}{$\begin{array}{l}\text { sparśa } \\
\text { (Stop) }\end{array}$} & \multicolumn{2}{|c|}{$\begin{array}{l}\text { anunāsika } \\
\text { (Nasal) }\end{array}$} & \multicolumn{2}{|c|}{$\begin{array}{l}\text { antastha } \\
\text { (Approximant) }\end{array}$} & \multicolumn{4}{|c|}{$\begin{array}{l}\text { ūṣma/samghashrī } \\
\text { (Fricative) }\end{array}$} \\
\hline & \multicolumn{4}{|c|}{ aghoșa } & \multicolumn{8}{|c|}{ ghoșa } & \multicolumn{2}{|c|}{ aghoșa } & \multicolumn{2}{|c|}{ ghoșa } \\
\hline & \multicolumn{2}{|c|}{ alpaprāna } & \multicolumn{2}{|c|}{ mahāprāna } & \multicolumn{2}{|c|}{ alpaprānna } & \multicolumn{2}{|c|}{ mahāprāna } & \multicolumn{4}{|c|}{ alpaprānna } & \multicolumn{4}{|c|}{ mahāproāna } \\
\hline & क & $\begin{array}{l}\mathrm{ka} \\
/ \mathrm{k} /\end{array}$ & ख & $\begin{array}{l}\text { kha } \\
/ k^{n /}\end{array}$ & ग & $\begin{array}{l}\text { ga } \\
/ g /\end{array}$ & घ & $\begin{array}{l}\text { gha } \\
/ g^{\dagger /} /\end{array}$ & ड॰ & $\begin{array}{l}\text { na } \\
\text { /ng }\end{array}$ & & & & & ह & $\begin{array}{l}\text { ha } \\
\text { /h/ }\end{array}$ \\
\hline $\begin{array}{c}\text { tālavya } \\
\text { (Palatal) }\end{array}$ & च & $\begin{array}{c}\mathrm{ca} \\
/ \mathrm{c}, \mathrm{t} / \mathrm{f}\end{array}$ & छ & $\begin{array}{l}\text { cha } \\
\mid c^{n}, \mathrm{tr}^{\mathrm{g}} /\end{array}$ & ज & j/, & झ & $\begin{array}{l}\text { jha } \\
4_{4}^{n}, \widehat{\mathrm{d}}^{n} /\end{array}$ & ज & $\begin{array}{l}\text { ก̃a } \\
/ \mathrm{n} /\end{array}$ & य & $\begin{array}{l}\text { ya } \\
\text { fj/ }\end{array}$ & श & $\begin{array}{c}\text { śa } \\
/ 6, \mathrm{fl}\end{array}$ & & \\
\hline $\begin{array}{l}\text { mūrdhanya } \\
\text { (Retroflex) }\end{array}$ & ट & $\begin{array}{l}\text { ta } \\
/ t /\end{array}$ & б & $\begin{array}{l}\text { tha } \\
/ \uparrow \% /\end{array}$ & ड & $\begin{array}{l}\text { da } \\
/ \mathrm{d} /\end{array}$ & ढ & $\begin{array}{l}\text { dha } \\
/ d^{\prime \prime}\end{array}$ & ण & $\begin{array}{l}\text { na } \\
\text { ln' }\end{array}$ & र & $\begin{array}{l}\mathrm{ra} \\
/ \mathrm{r} /\end{array}$ & ष & $\begin{array}{l}\text { sa } \\
/ \mathrm{s} /\end{array}$ & & \\
\hline $\begin{array}{l}\text { dantya } \\
\text { (Dental) }\end{array}$ & त & $\begin{array}{l}\text { ta } \\
\text { IV }\end{array}$ & थ & $\begin{array}{l}\text { tha } \\
\text { /t! } /\end{array}$ & द & $\begin{array}{l}\mathrm{da} \\
/ \mathrm{d} /\end{array}$ & ध & $\begin{array}{l}\text { dha } \\
\text { /d / }\end{array}$ & न & $\begin{array}{l}\text { na } \\
/ \mathrm{n} /\end{array}$ & ल & $\begin{array}{l}\text { la } \\
/ / I\end{array}$ & स & $\begin{array}{l}\text { sa } \\
/ \mathrm{s} /\end{array}$ & & \\
\hline $\begin{array}{l}\text { osțthya } \\
\text { (Labial) }\end{array}$ & प & $\begin{array}{l}\mathrm{pa} \\
\mathrm{pp} /\end{array}$ & फ & $\begin{array}{l}\text { pha } \\
/ p^{y} /\end{array}$ & ब & $\begin{array}{l}\mathrm{ba} \\
/ \mathrm{b} /\end{array}$ & भ & $\begin{array}{l}\text { bha } \\
/ b^{\star} / /\end{array}$ & म & $\begin{array}{l}\mathrm{ma} \\
\mathrm{/m} /\end{array}$ & व & $\begin{array}{l}\mathrm{va} \\
10 /\end{array}$ & & & & \\
\hline
\end{tabular}

(Source: https://en.wikipedia.org/wiki/Devanagari) 


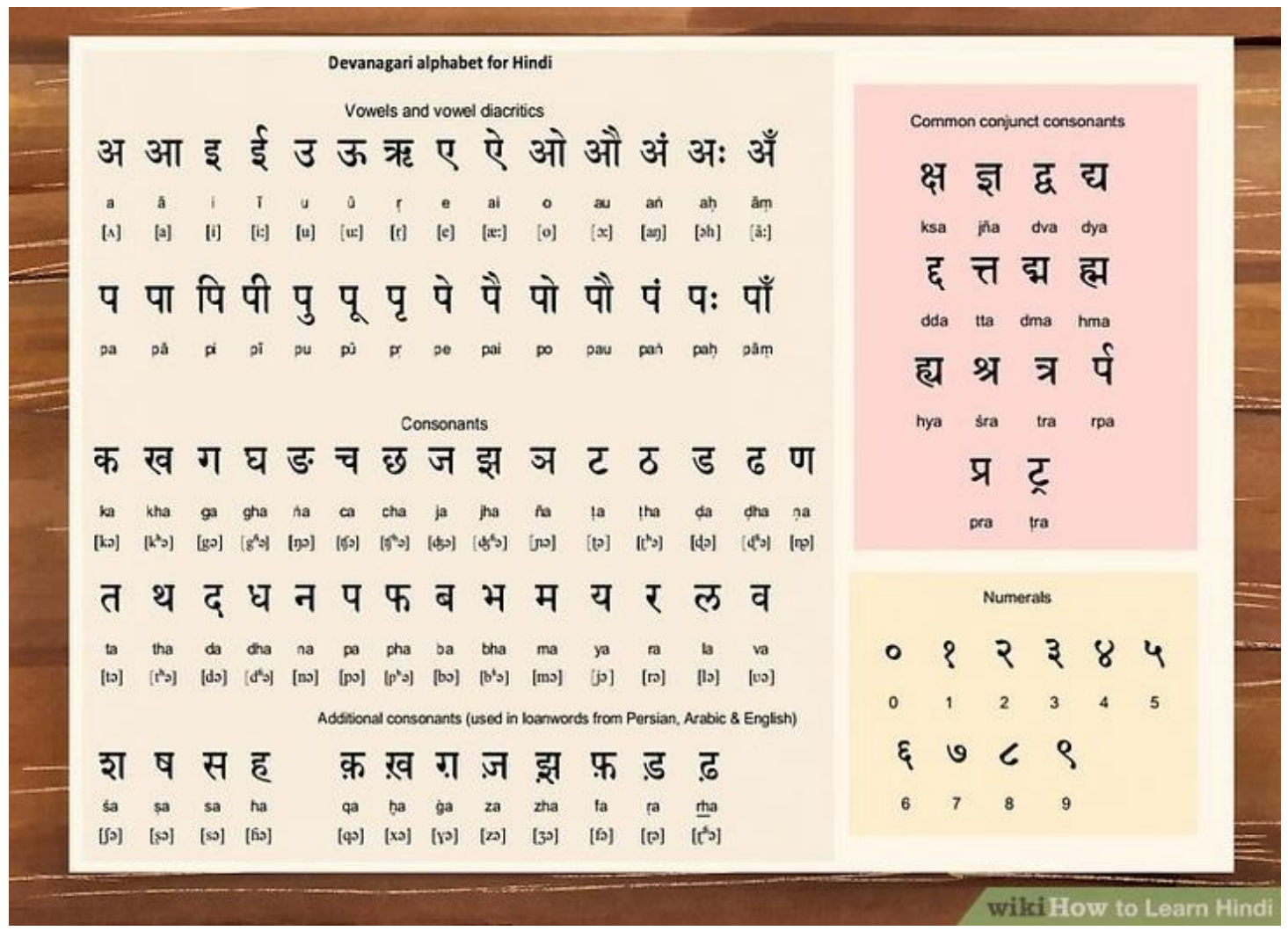

Fig. 1.

(https://www.wikihow.com/Learn-Hindi)

Since the article focuses on phonemes a description of the script/grapheme is beyond its purview and therefore is not being discussed in detail. The fact remains that nasalization exists in common man's speech and the same is being discussed here. The nasalised vowels are not considered to be independent phonemes and therefore no separate graphemes have been identified for them unlike the case with consonants. Nasalisation is phonemic in Hindi and different linguists have given different numbers. The nasalised vowel phonemes are different from the oral vowel phonemes. Thus one has to concede that the number of vowel phonemes which occur in Hindi is twenty. The details are shown in the following table:

Table 2

\begin{tabular}{|c|c|c|}
\hline $\begin{array}{l}\text { Total } N \text { of vowels in } \\
\text { Hindi: } 20\end{array}$ & Hindi vowel graphemes & Hindi vowels in IPA \\
\hline $\begin{array}{l}\text { Oral monophthongs: } \\
\text { (10) } \\
\text { (a part of Hindi } \\
\text { alphabet) }\end{array}$ & $\begin{array}{l}\text { अ, आ, इ, ई, उ, ऊ, ए, ऐ, } \\
\text { ओ, औ }\end{array}$ & $/ \curvearrowright, a_{:}, \mathrm{l}, \mathrm{i}:, \mathrm{u}, \mathrm{u}: \dot{\mathrm{e}}, \varepsilon, \mathrm{o}, \mathrm{\jmath} /$ \\
\hline $\begin{array}{l}\text { Oral diphthongs: }(2) \\
\text { (not a part of Hindi } \\
\text { alphabet) }\end{array}$ & अइ, अउ & /əI, əU / \\
\hline $\begin{array}{l}\text { Nasal monophthongs: } \\
\text { ( } 8 \text { ) } \\
\text { (not a part of Hindi } \\
\text { alphabet) }\end{array}$ & अँ, आँ, इँ, ई, उँ, ऊँ, ऐँ, औँ & 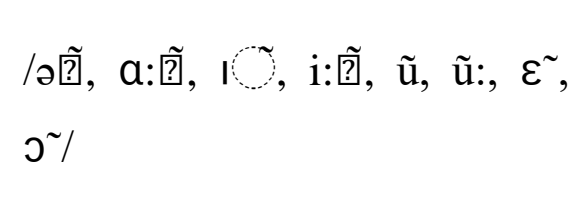 \\
\hline
\end{tabular}


While ten of them are pure vowels or oral monophthongs, two are oral diphthongs eight of them, namely (अँ, आँ, इँ, ईँ, उँ, ऊँ, ऐँ, औँ) are nasalized vowel phonemes. Let us now describe them. First of all let us take up the oral monophthongs:

\section{1. $/ \mathrm{a} /($ अ)}

The vowel phoneme /a/ is a central or middle phoneme as in order to articulate it the middle part of the tongue is raised to a point exactly in the middle of the halfclose and half-open positions, the lips remain unrounded and the air is released only through the oral cavity as the soft palate is raised to close the nasal passage. This vowel sound occurs in Hindi words in all the three, namely, initial, medial and final positions. For example, it occurs in the initial position as the opening syllable in the following words:

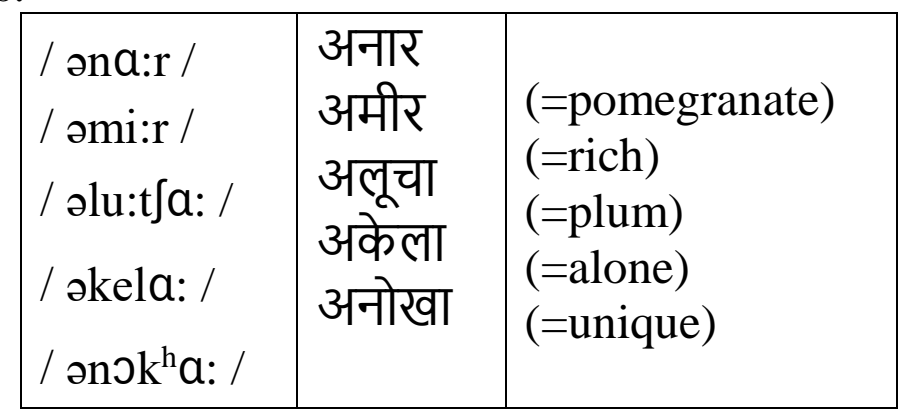

it occurs in the medial position as the terminating sound of the first syllable in the following words:

\begin{tabular}{|c|c|c|}
\hline $\begin{array}{l}\text { /məka:n / } \\
\text { /həl/ } \\
/ \mathrm{p}^{\mathrm{h}} \mathrm{l} /\end{array}$ & $\begin{array}{l}\text { मकान } \\
\text { हल } \\
\text { फल }\end{array}$ & $\begin{array}{l}\text { (=house) } \\
\text { (=plough; solution) } \\
\text { (=fruit; result); }\end{array}$ \\
\hline
\end{tabular}

And it occurs in the final position as the terminating sound of the last syllable in the following words:

\begin{tabular}{|c|c|c|}
\hline $\begin{array}{l}\text { /pəvittra/ } \\
\text { /t]ərıttra / } \\
\text { /mıtra/ }\end{array}$ & $\begin{array}{l}\text { पवित्र } \\
\text { चरित्र } \\
\text { मित्र }\end{array}$ & $\begin{array}{l}\text { (=sacred; pious) } \\
\text { (=character) } \\
\text { (=friend) }\end{array}$ \\
\hline
\end{tabular}

\section{2. $\quad / a: /(आ)$}

The Hindi vowel phoneme / $a$ :/ is a back vowel as in order to articulate it the back part of the tongue is kept at the open position, the lips remain neutral and the soft palate is raised so as to close the nasal passage with the result that the air is allowed to escane onlv through the oral nassage. This vowel nhoneme fioures in all Brahma Dutta Sharma

the opening syllable in the following words:

\begin{tabular}{|l|l|l|}
\hline /a:m / & आम & (=mango $)$ \\
\hline
\end{tabular}




\begin{tabular}{|l|l|l|}
\hline /a:fa:/ & $\begin{array}{l}\text { आशा } \\
\text { /a:dər/ }\end{array}$ & $\begin{array}{l}\text { (=hope) } \\
\text { (=respect) } \\
\text { (=age) }\end{array}$ \\
/a:ju / & आयु & \\
\hline
\end{tabular}

It occurs in the medial position as the terminating sound of a syllable in the following words:

\begin{tabular}{|l|l|l|}
\hline /Ina:m/ & $\begin{array}{l}\text { इनाम } \\
\text { आराम }\end{array}$ & $\begin{array}{l}\text { (=prize) } \\
\text { (=comfort) } \\
\text { (=saw-dust); }\end{array}$ \\
/bura:dda:/ & बुरादा & (=saw-dut \\
\hline
\end{tabular}

and it occurs in the final position as the terminating sound of the last syllable in words like:

\begin{tabular}{|c|c|c|}
\hline 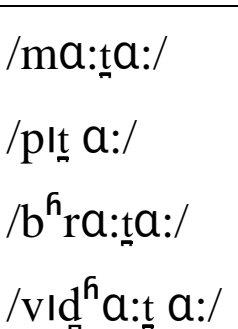 & $\begin{array}{l}\text { माता } \\
\text { पिता } \\
\text { भ्राता } \\
\text { विधाता }\end{array}$ & $\begin{array}{l}\text { (=mother) } \\
\text { (=father) } \\
\text { (=brother) } \\
\text { (=creator) }\end{array}$ \\
\hline
\end{tabular}

\section{3. / // (इ)}

The vowel phoneme $/ 1 /$ is a front vowel and in order to articulate it the retracted front part of the tongue is raised to a point slightly above the half- close position, the lips remain spread and the soft palate is raised so that the nasal passage is closed and the air escapes through the oral passage alone. This vowel phoneme occurs in all the three positions in the Hindi words. For example, it occurs in the initial position as the opening syllable in the following words:

\begin{tabular}{|l|l|l|}
\hline /Itılha:s/ & $\begin{array}{l}\text { इतिहास } \\
\text { इमला } \\
\text { /Imla:/ } \\
\text { इति }\end{array}$ & $\begin{array}{l}\text { (=history) } \\
\text { (=dictation) } \\
\text { (=end); }\end{array}$ \\
\hline
\end{tabular}

it occurs in the medial position as the terminating sound of some syllable in the following words:

\begin{tabular}{|c|c|c|}
\hline 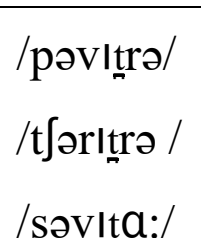 & $\begin{array}{l}\text { पवित्र } \\
\text { चरित्र } \\
\text { सविता }\end{array}$ & $\begin{array}{l}\text { (=holy) } \\
\text { (=character) } \\
\text { (=sun); and }\end{array}$ \\
\hline
\end{tabular}


it occurs in the final position as the terminating sound of the last syllable in the following words:

\begin{tabular}{|c|c|c|}
\hline $\begin{array}{l}\text { /hərl/ } \\
\text { /girl/ } \\
/|\mathrm{t}| / \\
/ \mathrm{a} \cdot \mathrm{d} / /\end{array}$ & $\begin{array}{l}\text { हरि } \\
\text { गिरि } \\
\text { इति } \\
\text { आदि }\end{array}$ & $\begin{array}{l}\text { (=the Supreme Being) } \\
\text { (=mountain) } \\
\text { (=end) } \\
\text { (=beginning). }\end{array}$ \\
\hline
\end{tabular}

\section{4. /i:/ (ई)}

The vowel phoneme /i:/ is a front vowel and in order to articulate it the advanced front part of the tongue is raised to a point slightly below the close position, the lips are spread, and the soft palate is raised so that the nasal passage is closed and the air escapes through the oral cavity alone.

This vowel phoneme occurs in all the three positions in Hindi words. For example it occurs in the initial position as the initial syllable in the following words:

\begin{tabular}{|c|c|c|}
\hline $\begin{array}{l}\text { /i:ma:n/ } \\
\text { /i:fa:n/ } \\
\text { /i:[vər/ }\end{array}$ & $\begin{array}{l}\text { ईमान } \\
\text { ईशान } \\
\text { ईश्वर }\end{array}$ & $\begin{array}{l}\text { (=probity) } \\
\text { (=north-east) } \\
\text { (=the Supreme Being); }\end{array}$ \\
\hline
\end{tabular}

it occurs in the medial position as the terminating sound of some syllable in the following words:

\begin{tabular}{|l|l|l|}
\hline /pərl:kJa:/ & परीक्षा & (=examination) \\
/dii:kJa:/ & दीक्षा & (=training) \\
/mi:l/ & मील & (=mile); \\
\hline
\end{tabular}

and it occurs in the final position as the terminating sound of the last syllable in the following words:

\begin{tabular}{|c|c|c|}
\hline $\begin{array}{l}\text { /goli:/ } \\
\text { /b } \\
\text { /həri:// } \\
\text { /səhi:/ }\end{array}$ & $\begin{array}{l}\text { गली } \\
\text { भली } \\
\text { हरी } \\
\text { सही }\end{array}$ & $\begin{array}{l}\text { (=street) } \\
\text { (=gentle [feminine gender]) } \\
\text { (=green [feminine gender] }) \\
\text { (=right) }\end{array}$ \\
\hline
\end{tabular}

\section{5. $/ \mathrm{u} /(\widetilde{3})$}

The vowel phoneme /u/ is a back vowel in order to articulate which the back part of the tongue near the centre is raised to a point slightly above the half-close position, the lips are rounded, and the air escapes exclusively through the oral passage. 
This vowel phoneme occurs in all the three positions in English words. For example, it occurs in the initial position as the opening syllable in the following words:

\begin{tabular}{|c|c|c|}
\hline $\begin{array}{l}\text { /ullu:/ } \\
\text { /upa:səna:/ } \\
\text { /ustəra:/ }\end{array}$ & $\begin{array}{l}\text { उल्लू } \\
\text { उपासना } \\
\text { उस्तरा }\end{array}$ & $\begin{array}{l}\text { (=owl) } \\
\text { (=worship) } \\
\text { (=razor); }\end{array}$ \\
\hline
\end{tabular}

it occurs in the medial position as the terminating sound of some syllable in the following words:

\begin{tabular}{|c|c|c|}
\hline 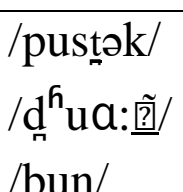 & $\begin{array}{l}\text { पुस्तक } \\
\text { धुआं } \\
\text { बन }\end{array}$ & $\begin{array}{l}\text { (=book) } \\
\text { (=smoke) } \\
\text { (=knit); }\end{array}$ \\
\hline
\end{tabular}

and it occurs in the final position as the terminating sound of the last syllable in the following words:

\begin{tabular}{|l|l|l|}
\hline /Jətru/ & शत्रु & (=enemy) \\
$/ \mathrm{k}^{\mathrm{h}} \mathrm{lu} /$ & खलु & $\begin{array}{l}\text { (=definitely) } \\
\text { (=chin) }\end{array}$ \\
/hənu/ & हनु & . \\
\hline
\end{tabular}

\section{6. $\quad$ /u:/ (ऊ)}

The vowel phoneme /u:/ is a back vowel. In order to articulate this vowel sound the far back part of the tongue is raised to a point slightly below the close position, the lips are rounded and the air is allowed to escape only through the oral passage.

This speech sound occurs in all the three positions in Hindi words. For example, it occurs in the initial position as the opening syllable in the following words:

\begin{tabular}{|l|l|l|}
\hline /u:tək/ & ऊतक & (=tissue) \\
/u:fa:/ & ऊषा & (=dawn) \\
/u:sər/ & ऊसर & (=barren); \\
\hline
\end{tabular}

Vowel Phonemes In Hindi

following words:

\begin{tabular}{|c|c|c|}
\hline $\begin{array}{l}\text { /su:ər/ } \\
\text { /tfu:ha:/ }\end{array}$ & $\begin{array}{l}\text { सूअर } \\
\text { चूहा } \\
\text { रूस }\end{array}$ & $\begin{array}{l}\text { (=hog) } \\
\text { (=rat) } \\
\text { (=Russia); }\end{array}$ \\
\hline
\end{tabular}

and it occurs in the final position as the terminating sound of the last syllable in the following words: 


\begin{tabular}{|c|c|c|}
\hline $\begin{array}{l}\text { /t } \int \mathrm{a}: \mathrm{ku}: / \\
/ \mathrm{ka}: \mathrm{d} 3 \mathrm{~s}: / \\
/ \mathrm{b}^{\mathrm{h}} \mathrm{a}: \mathrm{lu}: /\end{array}$ & $\begin{array}{l}\text { चाकू } \\
\text { काजू } \\
\text { भालू }\end{array}$ & $\begin{array}{l}\text { (=knife) } \\
\text { (=cashew nut) } \\
\text { (=bear). }\end{array}$ \\
\hline
\end{tabular}

\section{7. $\quad / \dot{\mathrm{e}} /$ (ए)}

The Hindi vowel phoneme $/ \dot{\mathrm{e}} /$ is a front vowel as in order to articulate it the advanced front part of the tongue is raised to a point slightly above the half-close position, the lips are kept in the spread shape and the air is allowed to escape only through the oral passage.

This vowel phoneme occurs in all the three positions in Hindi words. For example, it occurs in the initial position as the opening syllable in the following words:

\begin{tabular}{|c|c|c|}
\hline $\begin{array}{l}\text { /èk/ } \\
\text { /èri / } \\
\text { /ėka:nt / }\end{array}$ & $\begin{array}{l}\text { एक } \\
\text { एड़ी } \\
\text { एकांत }\end{array}$ & $\begin{array}{l}\text { (=one) } \\
\text { (=heel) } \\
\text { (=solitude); }\end{array}$ \\
\hline
\end{tabular}

it occurs in the medial position as the terminating sound of some syllable in the following words:

\begin{tabular}{|l|l|l|}
\hline /bèl/ & $\square \square \square$ & (=creeper) \\
/prèm/ & $\square \square \square \square \square$ & $\begin{array}{l}\text { (=love) } \\
\text { (=friendship); } \\
\text { /mèl/ }\end{array}$ \\
\hline
\end{tabular}

and it occurs in the final position as the terminating sound of the last syllable in the following words:

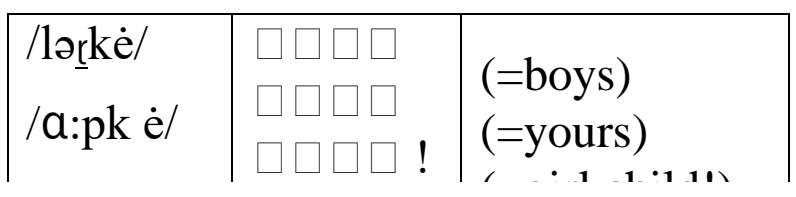

Brahma Dutta Sharma

$$
\text { 8. / / / (ऐ) }
$$

The vowel phoneme / $\varepsilon /$ is a front vowel as in order to articulate it the advanced front part of the tongue is raised to the half-open position the lips are kept neutrally spread and the air is allowed to escape through the oral cavity.

This Hindi vowel phoneme figures in all the three positions. For example, it figures in the initial position as the opening syllable in the following words:

\begin{tabular}{|l|l|l|}
\hline$/ \varepsilon n ə k /$ & $\square \square \square$ & (=spectacles) \\
(=luxury) \\
$/ \varepsilon \int /$ & $\square \square$ & (=Erawat [a name] ); \\
\hline
\end{tabular}




\begin{tabular}{|l|l|l|}
\hline /Era:üㅁt & & \\
\hline
\end{tabular}

it occurs in the medial position as the terminating sound of some syllable in words like:

\begin{tabular}{|c|c|c|}
\hline $\begin{array}{l}\text { /즈sa:/ } \\
\text { /토sa:/ } \\
/ \ln \varepsilon s a \cdot /\end{array}$ & $\begin{array}{l}\square \square \square \square \\
\square \square \square \square \\
\square \square \square \square\end{array}$ & $\begin{array}{l}(=\text { like }) \\
(=\text { how }) \\
(=\text { money }) .\end{array}$ \\
\hline
\end{tabular}

And it occurs in the final position as the terminating sound of the last syllable in words like:

\begin{tabular}{|l|l|l|}
\hline$/ \mathrm{h} \varepsilon /$ & $\square \square$ & (= is $)$ \\
$/ \mathrm{k} \varepsilon /$ & $\square \square$ & $\begin{array}{l}\text { (= vomit) } \\
\text { (= on) }\end{array}$ \\
$/ \mathrm{p} \varepsilon /$ & $\square \square$ & \\
\hline
\end{tabular}

It makes pairs of sounds:

\begin{tabular}{|c|c|c|}
\hline 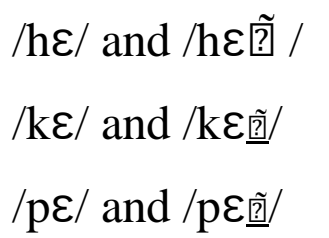 & $\begin{array}{l}\square \square \square \text { (= are) } \\
\square \square \square \text { (= a cry of pain) } \\
\square \square \square \text { (= a sound of a } \\
\text { horn) }\end{array}$ & $\begin{array}{l}\square \square \text { (=is) } \\
\square \square \\
\text { (=vomit) } \\
\text { पै (=on) }\end{array}$ \\
\hline
\end{tabular}

\section{9. $/ \mathrm{o} /($ )}

This Hindi phoneme is a back vowel and in order to articulate it the far back part of the tongue is raised to the half-close position, the lips are rounded, and the air is allowed to escape through the oral passage. It occurs in all the three, (namely, initial, medial, and final) positions in Hindi words. For example, it occurs in the initial position as the opening syllable in the following words:

\begin{tabular}{|l|l|l|}
\hline /ol a:/ & $\square \square \square$ & (=hail) \\
/os/ & $\sqcup \sqcup$ & (=dew); \\
\hline
\end{tabular}

Vowel Phonemes In Hindi

it occurs in the medial position as the terminating sound of some syllable in the following words:

\begin{tabular}{|c|c|c|}
\hline $\begin{array}{l}/ \underline{\mathrm{k}}^{\mathrm{h}} \mathrm{ol} / \\
/ \underline{\mathrm{go}} / / \\
/ \mathrm{bol} /\end{array}$ & $\begin{array}{l}\square \square \square \\
\square \square \square \\
\square \square \square\end{array}$ & $\begin{array}{l}\text { (= open }) \\
(=\text { round }) \\
(=\text { speak }(\text { v.i. })\end{array}$ \\
\hline
\end{tabular}

and it occurs in the final position as the terminating sound of the last syllable in words like:

\begin{tabular}{|l|l|l|}
\hline$/ \mathrm{lo} /$ & $\begin{array}{l}\square \square \\
\square \square \square\end{array}$ & $\begin{array}{l}\text { (=take) } \\
\text { (=go) }\end{array}$ \\
\hline
\end{tabular}




\begin{tabular}{|l|l|l|}
\hline /궁: & $\square \square \square$ & (=weep) \\
/roo/ & & \\
\hline
\end{tabular}

10. $/ \mathrm{J}$ (औ)

This vowel phoneme is a back vowel in order to articulate which the back part of the tongue is raised to the half-open position, the lips are rounded and the air is allowed to escape only through the oral passage. It occurs in all the three positions in Hindi words. For example, it occurs in the initial position as the opening syllable in the following words:

\begin{tabular}{|c|c|c|}
\hline 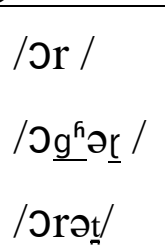 & $\begin{array}{l}\square \square \\
\square \square \square \\
\square \square \square\end{array}$ & $\begin{array}{l}\text { (=and) } \\
\text { (= a kind of ascetic) } \\
\text { (=woman); }\end{array}$ \\
\hline
\end{tabular}

it occurs in the medial position as the terminating sound of some syllable in words like:

\begin{tabular}{|c|c|c|}
\hline $\begin{array}{l}/ \mathrm{mod} 3 / \\
\text { /dola:/ } \\
\text { /hole/ }\end{array}$ & $\begin{array}{l}\square \square \square \\
\square \square \square \square \\
\square \square \square \square\end{array}$ & $\begin{array}{l}\text { (=happiness); } \\
\text { (=a raised boundary line) } \\
\text { (=slowly) }\end{array}$ \\
\hline
\end{tabular}

and it occurs in the final position as the terminating sound of the last syllable in words like:

Brahma Dutta Sharma

\begin{tabular}{|l|l|l|}
\hline /so/ & $\square \square$ & \\
/po/ & $\square \square$ & (=hundred) \\
/ro/ & $\square \square$ & $\begin{array}{l}\text { (=dawn) } \\
\text { (=flood) } \\
\text { (=flame). }\end{array}$ \\
/lo/ & $\square \square$ &
\end{tabular}

Now I come to the oral diphthongs:

11. /al/ (अइ)

This Hindi vowel phoneme is a diphthong in order to articulate which the tongue glides from the /a/ position (central, exactly between half-open and halfclose, unrounded) towards the / $1 /$ position (front, close, unrounded). It occurs in words like:

\begin{tabular}{|c|c|c|}
\hline $\begin{array}{l}\text { /gəlja:/ } \\
\text { /məlja:/ } \\
\text { /乩əlja:/ }\end{array}$ & 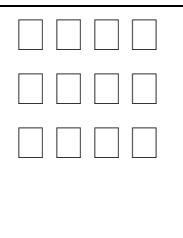 & $\begin{array}{l}(=\text { cow }) \\
\text { (=mother) } \\
\text { (=brother) }\end{array}$ \\
\hline
\end{tabular}




\section{2. $/ \partial \mho /(अ उ)$}

This vowel phoneme of Hindi is a diphthong in order to articulate which the tongue glides from the /a/ position (central, between half-open and half-close, unrounded) towards the $/ \mathrm{u} /$ position (far back, close, rounded). It occurs in the medial position in words like;

\begin{tabular}{|l|l|l|}
\hline /kəva:/ & $\square \square \square$ & (=crow) \\
/həva:/ & $\square \square \square$ & $\begin{array}{l}\text { (=a terrifying object/ person) } \\
\text { (=one fourth); }\end{array}$ \\
/pəva:/ & & $\square \square$
\end{tabular}

and it occurs in the final position as the terminating sound of the final syllable in words like:

\begin{tabular}{|l|l|l|}
\hline /gov/ & गौ & $(=\mathrm{cow})$. \\
\hline
\end{tabular}

Now I come to the nasalized vowel phonemes:

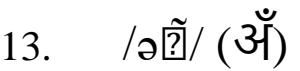

The Hindi vowel phoneme / /ə) $/$. When we articulate it the middle part of the tongue is raised to a point exactly between the half-close and the half-open positions, the lips remain neutral and the air flows outwards through both the oral and the nasal passages. It occurs in the initial position in words like:

\begin{tabular}{|c|c|c|}
\hline 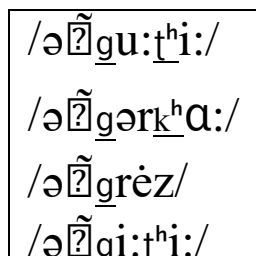 & $\begin{array}{l}\text { अँगूठी } \\
\text { अँगरखा } \\
\text { अँग्रेज़ } \\
\text { अँगीठी }\end{array}$ & $\begin{array}{l}\text { (=ring) } \\
\text { (=cloak) } \\
\text { (=Englishman) } \\
\text { (=grate); }\end{array}$ \\
\hline
\end{tabular}

and it occurs in the medial position in words like:

\begin{tabular}{|c|c|c|c|}
\hline $\ln \tilde{\mathrm{n}} \boldsymbol{\mathrm { n }}$ & फँमना & $(=$ to oet entanoled $)$ & \\
\hline /hə)ิ̃ิsna:/ & 6Nil & 0 & \\
\hline
\end{tabular}

This vowel phoneme is different from the cluster/on/ which occurs in the initial position in words like /ong/ अड्गूर (=grape), /ong/ अड्र् (=limb), and /onk/ अड्क. (=number).

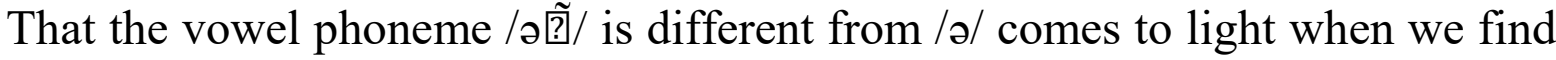
that the replacement of one by the other in a word changes its meaning. Here are some examples to illustrate the fact:

\begin{tabular}{|c|c|c|}
\hline 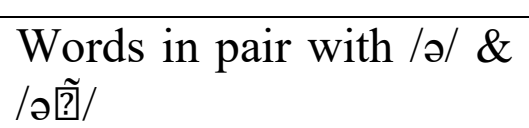 & Words with /ə/ & 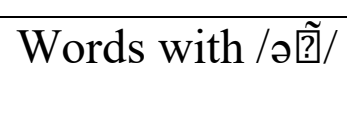 \\
\hline 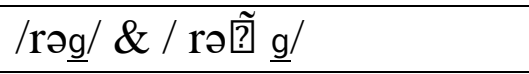 & रग (=nerve) & रँग (=colour) \\
\hline
\end{tabular}




\begin{tabular}{|c|c|c|}
\hline 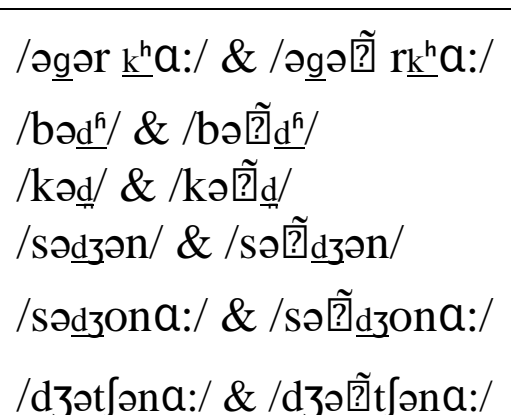 & $\begin{array}{l}\text { अगर खा (=eat the agar) } \\
\text { बध (=murder) } \\
\text { कद (=height) } \\
\text { सजन (= beloved) } \\
\text { सजोना (=Do beautify yourself) } \\
\text { जचना (= to look smart) }\end{array}$ & $\begin{array}{l}\text { अँगरखा (=cloak) } \\
\text { बँध (=get tied) } \\
\text { कँद (=get scratched) } \\
\text { सँजन (= to collect) } \\
\text { सँजोना (= to put in order) } \\
\text { जँचना (= to get examined) }\end{array}$ \\
\hline
\end{tabular}

In each of these cases the first syllable of the word in the first list has the vowel $/ \mathrm{a} /$ but it has been replaced by /a ? ? $/$ in the word in the second list with the result that the meaning of the word has changed.

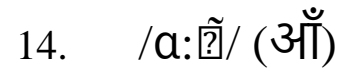

The vowel phoneme /a:艿/ is the nasalized form of /a:/. This vowel phoneme is a back vowel and in order to articulate it one raises the retracted back part of the tongue to the open position, keeps the lips in the neutral or unrounded shape and lets the air flow out through both the oral and the nasal passages. This phoneme occurs in all the three positions in the Hindi words. For example it occurs in the initial position as the initial syllable in the following words:

\begin{tabular}{|c|c|c|}
\hline 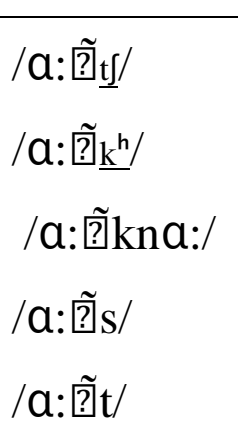 & $\begin{array}{l}\text { आँच } \\
\text { आँख } \\
\text { आँकना } \\
\text { आँस } \\
\text { आँट }\end{array}$ & $\begin{array}{l}\text { (=fire) } \\
\text { (=eye) } \\
\text { (=to estimate) } \\
\text { (=dissonance), and } \\
\text { (=restriction). }\end{array}$ \\
\hline
\end{tabular}

Brahma Dutta Sharma

words like:

\begin{tabular}{|c|c|c|}
\hline 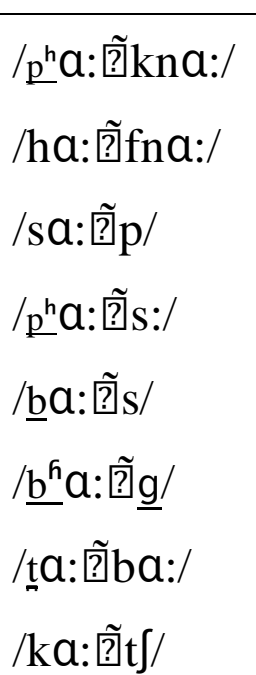 & $\begin{array}{l}\text { फाँकना } \\
\text { हाँफना } \\
\text { साँप } \\
\text { फाँस } \\
\text { बाँस } \\
\text { भाँग } \\
\text { ताँबा } \\
\text { काँच } \\
\text { धाँस }\end{array}$ & $\begin{array}{l}\text { (=to throw into the mouth) } \\
\text { (=to pant) } \\
\text { (=snake) } \\
\text { (=wedge) } \\
\text { (=a kind of reed plant) } \\
\text { (=a drug) } \\
\text { (= copper) } \\
\text { (=rectum; glass), and } \\
\text { (=a small splinter of wood); }\end{array}$ \\
\hline
\end{tabular}


/dn ${ }_{n}^{\mathrm{h}} \mathrm{a}:$ ?ิ? $\mathrm{s} /$

and it occurs in the final position as the terminating sound of the last syllable in words like:

\begin{tabular}{|c|c|c|}
\hline 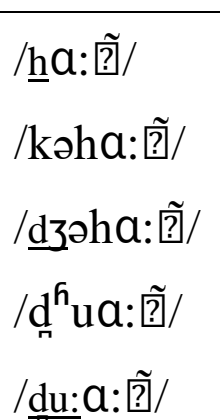 & $\begin{array}{l}\text { हाँ } \\
\text { कहाँ } \\
\text { जहाँ } \\
\text { धुआं } \\
\text { दूआं }\end{array}$ & $\begin{array}{l}\text { (=yes) } \\
\text { (=where) } \\
\text { (=universe) } \\
\text { (=smoke), and } \\
\text { (=a type of mustard seed). }\end{array}$ \\
\hline
\end{tabular}

This nasalized form of the Hindi vowel phoneme / $a$ :/ is different from the vowel phoneme /a:癷/ because the replacement of one by the other changes the meaning of the word in a large number of cases. Here are some of the examples:

\begin{tabular}{|c|c|}
\hline Word with /a:/ & Word with /a:苂/ \\
\hline$/ a: k^{h} /$ आख (=a herb) & 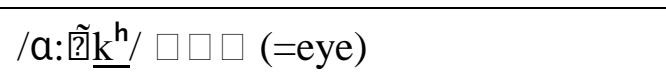 \\
\hline /ka:s/ कास (=cough) & /ka:@्रिs/ काँस (=a plant) \\
\hline /kəha:/ कहा (=uttered) & /kəha:[̃]/ कहाँ (=where) \\
\hline$/ \underline{b^{h}} a: p /$ भाप (=vapour) & $/ \underline{b^{h}} \mathrm{a}:$ 囚ิp/ भाँप (=sense) \\
\hline /ba:t/ बाट (=footpath) & /ba:Ø̃t/ बाँट (=divide) \\
\hline /ba:s/ बास (=bad smell) & 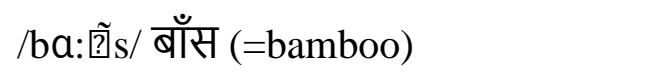 \\
\hline /sa: $\underline{\mathrm{g}}$ साग (=curry of leaves) & /sa:包/ साँग (=drama) \\
\hline /b $\underline{\mathrm{h}^{\mathrm{h}}} \mathrm{a}: \underline{\mathrm{g}} /$ भाग (=portion; run) & / $\underline{b}^{\mathrm{h}} \mathrm{\alpha}:$ ฮ̃g/ भाँग (=Indian hemp) \\
\hline \multirow[t]{2}{*}{$/ \underline{p}^{\mathrm{h}} \mathrm{a}: \underline{\mathrm{k}} \mathrm{a}: /$ फाका (=starvation) } & /p ${ }^{\mathrm{h}} \mathrm{a}: \tilde{\mathrm{I}} \mathrm{k} \mathrm{a}: /$ फाँका (=threw into mouth) \\
\hline & Vowel Phonemes In Hin \\
\hline /sa: $\underline{t^{\mathrm{h}} / \text { साठ (=sixty) }}$ & 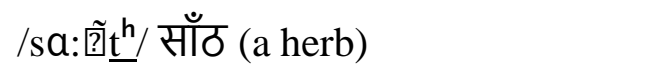 \\
\hline /k $\mathrm{k}: \mathrm{t} / /$ काच (=dirty mud) & 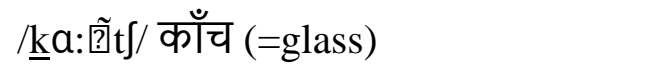 \\
\hline /pa:k $\mathrm{k}^{\mathrm{h}}$ पाख (=fortnight) & 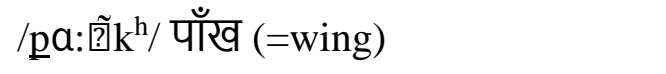 \\
\hline$/ \mathrm{k}^{\mathrm{h}} \mathrm{a}: \mathrm{s} /$ खास (=chief) & $/ \mathrm{k}^{\mathrm{h}} \mathrm{\alpha}: \tilde{\mathrm{Q}} \mathrm{s} /$ खाँस (=cough) \\
\hline /sa:s/ सास (=mother-in-law) & 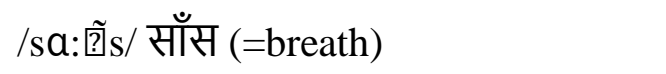 \\
\hline /da:t/ डाट (=cork) & 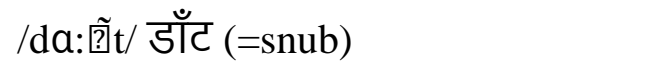 \\
\hline /ba:s/ बास (=bad smell) & /ba:@्वs/ बाँस (=bamboo) \\
\hline /sa: $\underline{\mathrm{g}} /$ साग (=leaf curry) & /sa:?̃̃g/ साँग (=stage play) \\
\hline /p ${ }^{\mathrm{h}} \mathrm{a}: \mathrm{t} /$ फाट (=cleave) & / $\mathrm{p}^{\mathrm{h}} \mathrm{a}: \widetilde{Ð} \mathrm{t} /$ फाँट (= to smash of an edible) \\
\hline
\end{tabular}




\begin{tabular}{|c|c|}
\hline /ba:t/ बाट (=footpath) & /ba:?्?̃t/ बाँट (=distribute) \\
\hline / $\underline{b}^{\mathrm{h}} \mathrm{a}: \mathrm{r} /$ भाड़ (=furnace) & / $\underline{b}^{\hbar} a:$ ?ี $r /$ भाँड़ (=jester) \\
\hline /pa:s/ पास (=near) & /pa:色/ पाँस (=trap) \\
\hline$/ \underline{\mathrm{d}} 3^{\mathrm{h}} \mathrm{a}: \underline{\mathrm{g}} /$ झाग (=foam) & 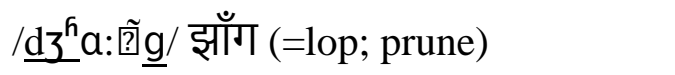 \\
\hline /ra: $\underline{g} /$ राग (=song; tune) & /ra:司/ राँग (a metal) \\
\hline / $\underline{b^{h}} a: \underline{d 3^{h}} i: /$ भाजी (=vegetable curry) & / $\underline{b}^{\mathrm{h}} \mathrm{a}: \tilde{\hat{?}} \mathrm{~d} \mathrm{z}^{\mathrm{h}} \mathrm{i}: /$ भाँजी (=adverse comment) \\
\hline /ba:j/ बाय (=a disease) & 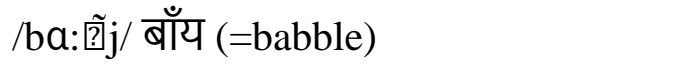 \\
\hline /a:ka:/ आका (=boss) & /a: ?̃रa:/ आँका (=estimated) \\
\hline /ra: $\underline{\mathrm{d}^{\mathrm{h}} / \text { राध (=pus) }}$ & 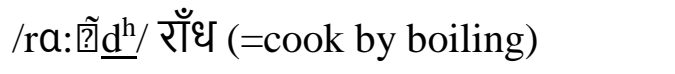 \\
\hline /a: $\underline{\mathrm{d}^{\mathrm{h}} \mathrm{i}}$ :/ आधी (=half [feminine]) & 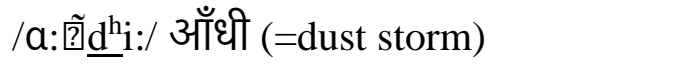 \\
\hline$/ \mathrm{k}^{\mathrm{h}} \mathrm{a}: /$ खा (=eat) & $/ \mathrm{k}^{\mathrm{h}} \mathrm{a}$ :व̃?/ खाँ (a surname of a clan) \\
\hline /ha:/ हा (an interjection) & 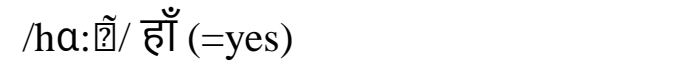 \\
\hline /ka:/ का (=what) & 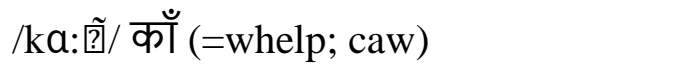 \\
\hline /ba:g/ बाग (=garden) & 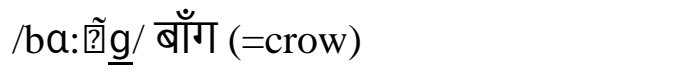 \\
\hline /ha:j/ हाय (an interjection of grief) & /ha: [थ]j/ हाँय (=affirmation) \\
\hline /ba:d $\mathrm{d}^{\mathrm{h}} \mathrm{a}: /$ बाधा (=obstacle) & 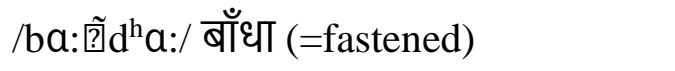 \\
\hline /kəha:/ कहा (=uttered) & 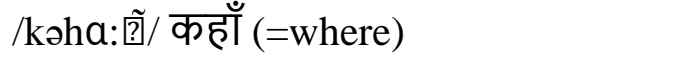 \\
\hline /da:t/ दात (=dowry) & /da: ?్̃t/ दाँत (=tooth) \\
\hline /da:ta:/ दाता (=giver) & 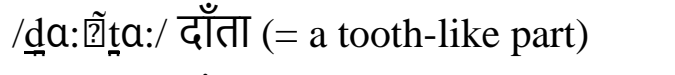 \\
\hline /sa:ki:/ साकी (=a maid serving wine) & /sa:?्?ki:/ साँकी (an agricultural tool) \\
\hline /a:ta:/ आटा (=flour) & 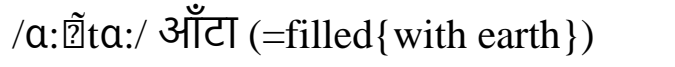 \\
\hline / $\underline{g}^{\mathrm{h}} \mathrm{a}: \mathrm{ti}: /$ घाटी (=valley) & / $\underline{g}^{\mathrm{h}} \mathrm{a}:$ ?ีti:/ घाँटी (a disease) \\
\hline /ma:/ मा (=no) & 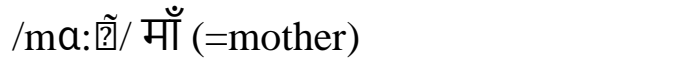 \\
\hline /na:d/ नाद (=sound) & /na:践/ नाँद (=tub) \\
\hline
\end{tabular}

\section{5. / / І監/ (इं)}

\section{Brahma Dutta Sharma}

centre is raised to a point slightly above the half-close position, the lips are kept loosely spread and the air is allowed to flow out through both the oral and the nasal passages. It occurs in the initial position as the first syllable in the following word:

\begin{tabular}{|c|c|c|}
\hline //甬la:s/ & इंग्लास & (=the court of a judge) \\
\hline
\end{tabular}

It occurs in the medial position as the last sound of some syllable in the following words: 


\begin{tabular}{|c|c|c|}
\hline 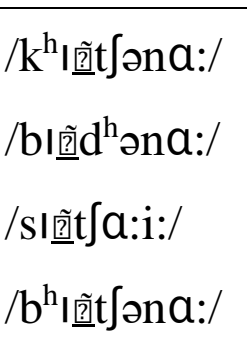 & $\begin{array}{l}\text { खिंचना } \\
\text { बिंधना } \\
\text { सिंचाई } \\
\text { भिंचना }\end{array}$ & $\begin{array}{l}\text { (= to get drawn/ pulled) } \\
\text { (= to get pierced through) } \\
\text { (= irrigation) } \\
\text { (= to get sandwiched) }\end{array}$ \\
\hline
\end{tabular}

This vowel phoneme is different from /国/ as the replacement of one by the other in several Hindi words results in the change of meaning. Here is an example:

/Igla:s/ इग्लास (= the name of a town) $\quad$ /I国la:s/ इंग्लास (=a judge's court).

\section{6. /i: / $/$ / (ई)}

This vowel phoneme is the nasalized form of the oral vowel phoneme /i:/. In order to articulate it the advanced front part of the tongue is raised to a point slightly below the close position, the lips remain spread, and the air is allowed to flow out through both the oral and the nasal passages. This phoneme occurs in all the three positions. For example, it figures in the initial position as the opening syllable in the following words:

\begin{tabular}{|c|c|c|}
\hline 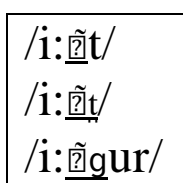 & $\begin{array}{l}\text { ईंट } \\
\text { ईंत } \\
\text { दंगार }\end{array}$ & $\begin{array}{l}\text { (=brick), } \\
\text { (=an insect like mosquito) } \\
\text { (=vermilion); }\end{array}$ \\
\hline
\end{tabular}

it occurs in the medial position as the last sound of some syllable in words like:

\begin{tabular}{|c|c|c|}
\hline 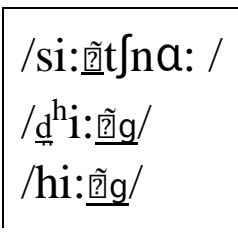 & $\begin{array}{l}\text { सींचना } \\
\text { धींग } \\
\text { हींग } \\
\text { nीं- }\end{array}$ & $\begin{array}{l}\text { (=to irrigate) } \\
\text { (=stout) } \\
\text { (=asafoetida) } \\
\text { (=sandwich tightly); }\end{array}$ \\
\hline
\end{tabular}

Vowel Phonemes In Hindi

and it figures in the final position as the terminating sound of the last syllable in words like:

\begin{tabular}{|c|c|c|}
\hline 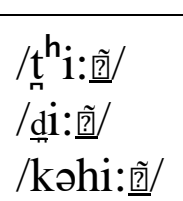 & $\begin{array}{l}\text { थीं } \\
\text { दीं } \\
\text { कहीं }\end{array}$ & $\begin{array}{l}\text { (=were [plural feminine]) } \\
\text { (=gave [plural feminine]) } \\
\text { (=somewhere). }\end{array}$ \\
\hline
\end{tabular}

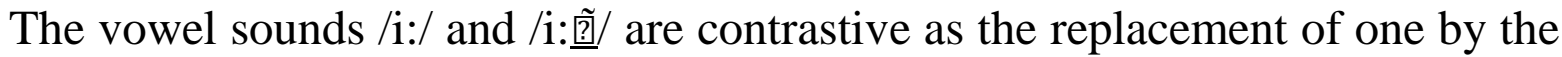
other changes the meaning of the word in many cases. Here are a few examples: 


\begin{tabular}{|c|c|c|c|}
\hline \multicolumn{2}{|c|}{ words with /i:/ } & \multicolumn{2}{|c|}{ words with /i:茴/ } \\
\hline $\begin{array}{l}\text { /tn }{ }^{\mathrm{h}} \mathrm{i}: / / \square \\
\text { /dii:/ दी } \\
\text { /kəhi:/ कही } \\
\text { /səhi:/ सही } \\
\text { /si:tra:/ सीता } \\
\text { /pi:/ पी } \\
\text { /b } \\
\text { hi: } \mathrm{t} / \text { भीत }\end{array}$ & $\begin{array}{l}\text { (= was) } \\
(=\text { gave }) \\
(=\text { said }) \\
(=\text { correct }) \\
\text { (=a [female name) } \\
\text { (=drink) } \\
\text { (= vexed) }\end{array}$ & 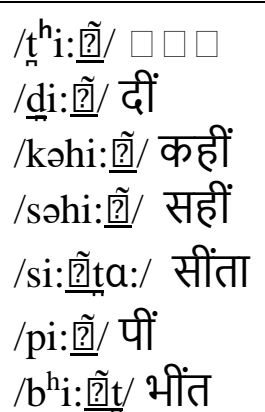 & $\begin{array}{l}\text { (=were [plural feminine]) } \\
\text { (=gave [plural feminine]) } \\
\text { (=somewhere) } \\
\text { (=tolerated) } \\
\text { (=sew/ stitch) } \\
\text { (=a sound of horn) } \\
\text { (=wall) }\end{array}$ \\
\hline
\end{tabular}

17. $/ \tilde{\mathrm{u}} /($ (उँ)

The vowel sound / $\tilde{\mathrm{u}} /$ is produced when the back part of the tongue is raised to a point slightly above the half close position, the lips are rounded and the air escapes through both the oral and the nasal passages. This vowel phoneme occurs in the initial and medial positions in Hindi words. It figures in the initial position in the following Hindi words:

\begin{tabular}{|c|c|c|}
\hline $\begin{array}{l}\text { /ũglı/ } \\
\text { /ũga:i:/ } \\
/ \text { /ũd }^{\mathrm{h}} \mathrm{a}: \mathrm{i}: / \\
/ \text { ũga:iè / }\end{array}$ & $\begin{array}{l}\text { उँगली } \\
\text { उँगाई } \\
\text { उँधाई } \\
\text { उँगाये }\end{array}$ & $\begin{array}{l}\text { (=finger) } \\
\text { (=overhauling) } \\
\text { (=spilled) } \\
\text { (=drowsy) }\end{array}$ \\
\hline
\end{tabular}

The sound occurs in medial position in words like:

\begin{tabular}{|c|c|c|}
\hline 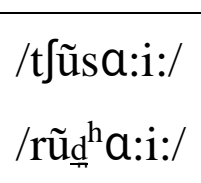 & $\begin{array}{l}\text { चुँसाई } \\
\text { रूँधाई } \\
\text { गाँधार्द }\end{array}$ & $\begin{array}{l}\text { (=sipping) } \\
\text { (=kneading) } \\
\text { (=kneading) }\end{array}$ \\
\hline
\end{tabular}

Brahma Dutta Sharma

This vowel phoneme is different from the vowel phoneme $/ \mathrm{u} /$ as the replacement of one by the other in a Hindi word results in the change of meaning. Here is an example:

\begin{tabular}{|c|c|}
\hline Words with /u/ & Words with /ũ/ \\
\hline /ugali:/ उगली (= vomited) & /ũgli:/ उँगली (=finger) \\
\hline /uga:jè/ उगाये $\quad$ (= grew $)$ & /ũga:jè/ उँगाये (=drowsy) \\
\hline $\begin{array}{l}\text { /ugva:jè उगवाये } \quad \text { (= made [one] } \\
\text { grow) }\end{array}$ & /ũgva:jè/ उँगवाये (made [one] overhaul) \\
\hline
\end{tabular}

18. /ũ:/ (ऊँ) 
The vowel phoneme /ũ:/ is a back vowel and in order to articulate it the far back part of the tongue is raised to a point slightly below the close position, the lips are rounded and the air is allowed to escape through both the oral and the nasal passages. This vowel phoneme occurs in all the three positions in English words. For instance, it figures in the initial position as the opening syllable in the following words:

\begin{tabular}{|c|c|c|}
\hline $\begin{array}{l}/ \tilde{\mathrm{u}}: \underline{t} / \\
/ \tilde{\mathrm{u}}: \mathrm{t} f \mathrm{a}: / \\
/ \tilde{\mathrm{u}}: \mathrm{g}^{\mathrm{h}} /\end{array}$ & $\begin{array}{l}\text { ऊँट } \\
\text { ऊँचा } \\
\text { ऊँघ }\end{array}$ & $\begin{array}{l}\text { (=camel) } \\
(=\text { high }) \\
(=\text { doze }) ;\end{array}$ \\
\hline
\end{tabular}

It figures in the medial position as the terminating sound of some syllable in such words as the following ones:

\begin{tabular}{|l|l|l|}
\hline$/$ pũt $\int^{\text {h/ }}$ & पूँछ & (=tail) \\
/ trũs/ & चूँस & (=suck) \\
/bũd / $/$ & बूँद & (= a drop) \\
/sũt/ & सूँत & (=drink through the nose); \\
\hline
\end{tabular}

and it figures in the final position as the terminating sound of the last syllable in words like:

\begin{tabular}{|c|c|c|}
\hline $\begin{array}{l}\text { /hũ:/ } \\
/ \underline{\mathrm{d} z a}: \tilde{u}: / \\
/ \mathrm{k}^{\mathrm{h}} \text { əra: ũ:/ }\end{array}$ & $\begin{array}{l}\text { हूँ } \\
\text { जाऊँ } \\
\text { खड़ाऊँ }\end{array}$ & $\begin{array}{l}(=\mathrm{am}) \\
(=[\text { May I ] go? } \\
\text { (=wooden slippers). }\end{array}$ \\
\hline
\end{tabular}

The vowel nhoneme /ı:/ and /ĩ:/ are contrastive as the renlacement of one bv Vowel Phonemes In Hindi example, in the following cases:

\begin{tabular}{|c|c|c|c|}
\hline \multicolumn{2}{|c|}{ word with /u:/ in it } & \multicolumn{2}{|c|}{ word with /ũ:/ in it } \\
\hline /bu:t/ & बूट (=shoe) & /bũ:t/ & बूँट (=gram pod) \\
\hline /su:t/ & सूत (=yarn) & /sũ:t/ & सूँत (=drink ) \\
\hline /ku:t $/ /$ & कूच (=departure) & /kũ:t $[/$ & कूँच (=pierce) \\
\hline /pu:dza:/ & पूजा (=worship) & /pũ:dza:/ & पूँजा (=strand of hemp) \\
\hline /ru:s/ & रूस (=Russia) & /rũ:s/ & रूस (= feel offended) \\
\hline /hu:s/ & हूस (=uncultured) & /hũ:s/ & हूँस (=thrash) \\
\hline$/ \underline{g}^{\mathrm{h}} \mathrm{u}: \mathrm{s} /$ & घूस (=bribe) & $/ \underline{g}^{h} \tilde{u}: s /$ & घूँस (=thrust) \\
\hline
\end{tabular}

19. $/ \varepsilon^{\sim} /(ऐ)$ 
The Hindi vowel phoneme $/ \varepsilon^{\sim} /$ is a front vowel in order to articulate which the advanced front part of the tongue is raised to the half-open position, the lips remain spread, and the air is allowed to flow out through both the oral and the nasal passages. This vowel phoneme occurs in all the three positions in Hindi words. For instance, it occurs in the initial position as the opening syllable in the words like:

\begin{tabular}{|c|c|c|}
\hline $\begin{array}{l}/ \varepsilon^{\tilde{t^{h}} /} \\
/ \varepsilon^{\tilde{t} t} \int \mathrm{kta}: \mathrm{na}: /\end{array}$ & $\begin{array}{l}\text { ऐँठ } \\
\text { ऐँचकताना }\end{array}$ & $\begin{array}{l}\text { (=snobbery) } \\
\text { (=misshaped); }\end{array}$ \\
\hline
\end{tabular}

it occurs in the medial position as the terminating sound of some syllable in words like:

\begin{tabular}{|l|l|l|}
\hline$/ \mathrm{p} \varepsilon^{\sim} \underline{t}^{\mathrm{h}} /$ & पैंठ & (=temporary market) \\
$/ \mathrm{s} \varepsilon^{\sim} \tilde{\mathrm{d}}^{\mathrm{h}} /$ & सैंध & (=break into) \\
$/ \underline{\mathrm{g}} \varepsilon^{\sim} \underline{\mathrm{d}} /$ & गैंद & (=ball); \\
\hline
\end{tabular}

and it occurs in the final position in words like:

\begin{tabular}{|c|c|c|}
\hline $\begin{array}{l}/ \operatorname{por}^{\mathrm{h}} \varepsilon^{\sim} / \\
/ \text { bol } \varepsilon^{\sim} / \\
/ \text { kare } /\end{array}$ & $\begin{array}{l}\text { पढ़ें } \\
\text { बोलें } \\
\text { करें }\end{array}$ & $\begin{array}{l}(=[\text { let them }] \text { read }) \\
(=[\text { let them }] \text { speak }) \\
(=[\text { let them }] \text { do }) .\end{array}$ \\
\hline
\end{tabular}

The vowel $/ \varepsilon^{\sim} /$ is a phoneme different from $/ \varepsilon /$ as the replacement of one by the other results in the change of meaning. For example, this happens in the following Brahma Dutta Sharma

\begin{tabular}{|c|c|}
\hline Word with $/ \varepsilon^{\sim} /$ & word with $/ \varepsilon /$ \\
\hline$/ \mathrm{p}^{\sim} \mathrm{t}^{\mathrm{h} /}$ पैंठ (=temporary market) & $/ \mathrm{p} \varepsilon \mathrm{t}^{\mathrm{h}} /$ पैठ (=access) \\
\hline$/ s \varepsilon^{\sim} \mathrm{t} /$ सैंत (=gratis) & /sعt/ सैत (=honey) \\
\hline$/ \underline{\mathrm{h}} \varepsilon^{\sim} /$ हैं (=are) & $/ \underline{h} \varepsilon /$ है (=is) \\
\hline$/ \mathrm{p} \varepsilon^{\sim} \mathrm{da}: /$ पैंदा (=bottom lid) & $/ p \varepsilon d a: /$ पैदा (=produce) \\
\hline
\end{tabular}

20. /5\% (औ)

The Hindi vowel phoneme / $/ \%$ is a back vowel and in order to articulate it the back part of the tongue is raised to the half-open position, the lips are rounded and 
the air flows out through both the oral and the nasal passages. It occurs in all the three positions. For instance, it occurs in the initial position as the initial syllable in words like:

\begin{tabular}{|c|c|c|}
\hline 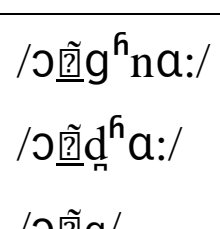 & $\begin{array}{l}\text { औँघना } \\
\text { औँधा } \\
\text { औँग }\end{array}$ & $\begin{array}{l}\text { (=to doze) } \\
\text { (=upside down) } \\
\text { (=overhaul); }\end{array}$ \\
\hline /0国g/ & & \\
\hline
\end{tabular}

It occurs in the medial position as the terminating sound of some syllable in words like:

\begin{tabular}{|c|c|c|}
\hline 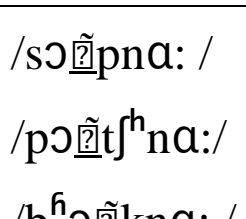 & $\begin{array}{l}\text { सौंपना } \\
\text { पौंछना } \\
\text { भौंकना }\end{array}$ & $\begin{array}{l}\text { (=to give custody [to]) } \\
\text { (=to wipe) } \\
\text { (=to bark); }\end{array}$ \\
\hline
\end{tabular}

and it occurs in the final position as the terminating sound of the final syllable in words like:

\begin{tabular}{|c|c|c|}
\hline 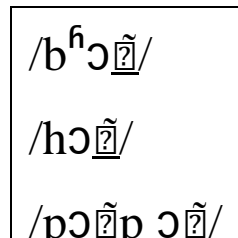 & $\begin{array}{l}\text { भौं } \\
\text { हौं } \\
\text { पौं-पों }\end{array}$ & $\begin{array}{l}\text { (=eye-brow }) \\
(=\mathrm{I}) \\
(=\text { motor-car })\end{array}$ \\
\hline
\end{tabular}

This vowel phoneme is different from / $\mathrm{O}$ / as one's replacement by the other in a Hindi word changes the meaning of the word. Here are some examples which illustrate this fact:

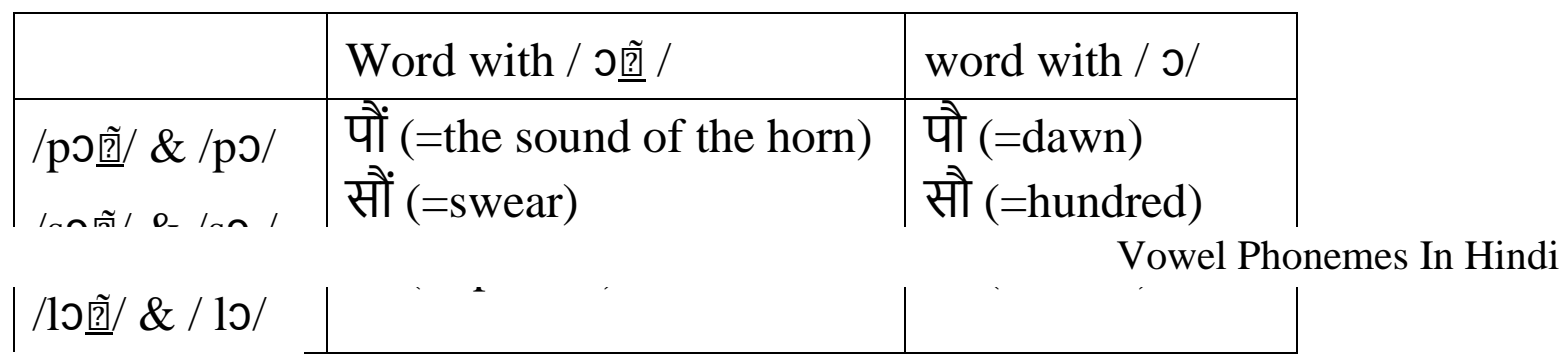

\section{Conclusions}

Thus one has to concede that there are twenty vowel phonemes in Hindi though some of them do not find a representation in Devanagari alphabet and in writing they are represented by slightly modified forms of the nine prevalent graphs.

\section{References}

Agnihotri, Rama Kant. (2007). Hindi: An Essential Grammar. London: Routledge.

Chatterjee, Suniti Kumar. (1942). Indo-Aryan and Hindi: Eight Lectures. Ahmedabad: Gujarat Vernacular Society. Retrieved from: https://archive.org/details/in.gov.ignca.2478) 
Duncan Forbes. (1846). A Grammar of the Hindustani Language in the Oriental and Roman Character, London: W. H. Allen \& Co. Retrieved from: (https://ia801408.us.archive.org/ 27/items/agrammarhindstn00forbgoog/agrammarhindstn00forbgoog.pdf).

Dwivedi, Kapildev. (2016). Bhasha vigyan evam bhasha shastra [Philology and Linguistics]. Varanasi: Vishvavidaya Prakashan.

Greaves, Edwin. (1921). Hindi Grammar. Allahabad: Indian Press.

Guru, Kamta Prasad. (2009 rpt. [1920]). Hindi Vyakaran [Grammar of Hindi]. New Delhi: Prakashan Sansthan.

Koul, Omkar N. (2008). Modern Hindi Grammar. Springfield: Dunwoody Press.

Pahwa, Thakardass. (1919). The Modern Hindustani Scholar; or, The Pucca Munshi. Jhalum: Printed at the Baptist Mission Press, Calcutta and published by the author.

Shakespear, John. (1845). An Introduction to the Hindustani Language. Comprising a Grammar, and a Vocabulary, English and Hindustani. London: Wm. H. Allen \& Co. Retrieved from: https://archive.org/details/introductiontohi00shakrich.

Sharan, Ram Lochan. (1920). Hindi Vyakaran Chandrodaya [Chandrodaya Hindi Grammar]. Darbhanga: Hindi Pustak Bhandar.

Sharma, Aryendra. (1994). A Basic Grammar of Hindi. Delhi: Central Hindi Directorate.

Tiwari, Bhola Nath. (1958). Hindi Bhasha ka Saral Vyakaran [A Simple Grammar of Hindi]. Delhi: Rajkamal.

Tiwari, Uday Narayan. (2009). Hindi Bhasha ka Udgam aur Vikas [Origin and Development of Hindi Language]. Allahabad: Lok Bharati, 2009.

Tweedie, J. (1900). Hindustani as It Ought to be Spoken. London: W. Thacker. Retrieved from: https://archive.org/details/hindstniasitoug00tweegoog/page/n6)

Verma, Ram Chandra. (1961) Manak Hindi Vyakaran [Standard Grammar of Hindi]. Varanasi: The Chaukhambha Vidya Bhawan.

\section{Sources}

www.wikihow.com/Learn-Hindi

https://en.wikipedia.org/wiki/Devanagari 